\title{
Growth inhibition and apoptosis induction by tanshinone $I$ in human colon cancer Colo 205 cells
}

\author{
CHIN-CHENG SU ${ }^{1,2,4}$, GUANG-WEI CHEN ${ }^{3,4}$ and JAUNG-GENG LIN ${ }^{4}$ \\ ${ }^{1}$ Division of General Surgery, Buddhist Tzu Chi General Hospital, No. 707; ${ }^{2}$ Tzu Chi University, No. 701, \\ Sec. 3, Chung Yang Road, Hualien 970; ${ }^{3}$ Department of Traditional Chinese Medicine, Chung-Ho Memorial \\ Hospital, Kaohsiung Medical University, No. 100, Tzyou 1st Road Kaohsiung 807; ${ }^{4}$ School of Chinese \\ Medicine, China Medical University, No. 91, Hsueh-Shih Road, Taichung City 404, Taiwan, R.O.C
}

Received June 5, 2008; Accepted July 30, 2008

DOI: $10.3892 /$ ijmm_00000063

\begin{abstract}
Tanshinone I (Tan-I) and tanshinone IIA (Tan-IIA) were isolated from Danshen (Salviae Miltiorrhizae Radix), a widely prescribed traditional herbal medicine that is used to treat cardiovascular and dysmenorrhea diseases. In our previous study, Tan-IIA was demonstrated to induce apoptosis in human colon cancer Colo 205 cells. However, the effect of Tan-I on human colon cancer cells is not clearly understood yet. In this study, the anti-growth and apoptosis-eliciting effects of Tan-I, as well as its cellular mechanisms of actions, were investigated in Colo 205 human colon cancer cells. Tan-I reduced cell growth in a concentration-dependent manner, inducing apoptosis accompanied by an increase in TUNEL staining and in cells in the sub-G1 fraction. The expression of p53, p21, bax and caspase-3 increased in Tan-I-treated cells. In addition, the cell cycle analysis showed G0/G1 arrest. These findings suggest that Tan-I induces apoptosis in Colo 205 cells through both mitochondrial-mediated intrinsic cell-death pathways and p 21-mediated G0/G1cell cycle arrest. Accordingly, the therapeutic potential of Tan-I for colon cancer deserves further study.
\end{abstract}

\section{Introduction}

Colon cancer is a major health problem in human of developed Western countries. The prognosis of colon cancer is still not satisfactory. The modulation of apoptotic response provided new hope for therapeutic strategies in cancer disease $(1,2)$. Many therapeutic agents were developed to induce the apoptotic process in target cells (3). Many compounds

Correspondence to: Dr Chin-Cheng Su, Buddhist Tzu Chi General Hospital, Hualien, Division of General Surgery, No 707, Sec. 3, Chung Yang Road, Hualien 970, Taiwan, R.O.C.

E-mail: succ.maeva@msa.hinet.net

Key words: tanshinone I, apoptosis, Colo 205, p21, bax, caspase-3 purified from plants have revealed anticancer activity, such as camptothecin (4) and taxol (5) that were able to induce cancer cells to apoptosis. Tan-I and Tan-IIA are derived from the plant of Danshen (Salviae miltiorrhizae Radix), the root of the traditional Chinese medicine, Salvia miltiorrhiza Bunge, which is widely used for cardiovascular and dysmenorrheal diseases (6). It is known that Tan-IIA exerts its anticancer activity on many human cancer cells (7-13). However, there is no available information to address the effects of Tan-I in human colon cancer cells. In the present study, human colon cancer Colo 205 cells were used to investigate the molecular mechanisms of Tan-I in human colon cancer.

\section{Materials and methods}

Chemicals and reagents. Tanshinone I (1,6-Dimethylphenanthro[1,2-b]furan-10,11-dione; $\mathrm{C}_{18} \mathrm{H}_{2} \mathrm{O}_{3}$ (Fig. 1), purity $>98 \%$, HPLC) was purchased from Herbasin Co. (Shenyang, China). Aprotinin, antipain, sodium deoxycholate, leupeptin, propidium iodide (PI), sodium orthovanadate, Triton X-100, Tris-HCl, ribonuclease-A and trypan blue were obtained from Sigma Chemical Co. (St. Louis, MO, USA). Dimethyl sulfoxide (DMSO), potassium phosphate and TE buffer were purchased from Merck Co. (Darmstadt, Germany). RPMI-1640 medium, fetal bovine serum (FBS), penicillin-streptomycin, trypsin-EDTA, and glutamine were obtained from Gibco BRL (Grand Island, NY, USA).

Human colon cancer cell line (Colo 205). The human colon cancer cell line (Colo 205: human colon adenocarcinoma) was obtained from the Food Industry Research and Development Institute (Hsinchu, Taiwan). The cells were placed into $75-\mathrm{cm}^{3}$ tissue culture flasks and grown at $37^{\circ} \mathrm{C}$ in humidified $5 \%$ $\mathrm{CO}_{2}$ and $95 \%$ air atmosphere in RPMI-1640 medium (Sigma Chemical Company), contained with $10 \%$ heat-inactivated fetal bovine serum, FBS (Gibco BRL), $10 \mathrm{mM}$ HEPES, $10 \mathrm{mM}$ sodium pyruvate (Gibco), $2 \%$ penicillin-streptomycin (10,000 U/ml penicillin; $10 \mathrm{mg} / \mathrm{ml}$ streptomycin), $1 \% 10 \mathrm{mM}$ HEPES, $1 \% 10 \mathrm{mM}$ sodium pyruvate and $1 \%$ glutamine. The data presented in this study are from at least 3 independent experiments. 
Cell viability assay. Colo 205 cells were plated in 6-well plate at a density of $2 \times 10^{5}$ cells per well and cultured in a humidified atmosphere with $5 \% \mathrm{CO}_{2}$ at $37^{\circ} \mathrm{C}$ for $24 \mathrm{~h}$. Then, Tan-I $(1,2.5$, 5 and $10 \mu \mathrm{g} / \mathrm{ml}$; stock solutions made in DMSO) was applied into the cultured cells for 24,48 , and $72 \mathrm{~h}$; control cells were treated with DMSO vehicle (final concentration $<0.5 \%$ ) in culture medium. The final concentration of DMSO was $<0.5 \%(\mathrm{v} / \mathrm{v})$, which did not affect cell growth. After treating with Tan-I 24, 48, and $72 \mathrm{~h}$, the cells were collected and their viability determined by trypan blue exclusion method.

Cell cycle analysis. The percentage of cells in sub-G1, G0/G1, S and G2/M phases were determined by flow cytometry as previously described (14). Briefly, $1 \times 10^{6}$ cultured Colo 205 cells in $10-\mathrm{cm}$ dishes were treated with different concentrations $(0,1,2.5,5$ and $10 \mu \mathrm{g} / \mathrm{ml})$ of Tan-I for 48 and $72 \mathrm{~h}$. The harvested cells were washed twice with PBS, fixed gently with ice-cold $70 \%$ ethanol overnight, and then resuspended in PBS containing $40 \mu \mathrm{g} / \mathrm{ml}$ propidium iodide, $0.1 \mathrm{mg} / \mathrm{ml}$ RNase (Sigma), and $0.1 \%$ Triton X-100. The cells were kept at $37^{\circ} \mathrm{C}$ for $30 \mathrm{~min}$ before the cell cycle was analyzed by flow cytometry (Becton-Dickinson, San Jose, CA, USA) using an argon laser at $488 \mathrm{~nm}$. The average of the percentage of each phase in the cell cycle was representative of the 3 independent experiments.

TUNEL assay. Apoptotic cells were identified using a commercially available kit based on the TdT-mediated dUTP nick end-labeling (TUNEL) method in accordance with the manufacturer's instructions (Roche Molecular Biochemicals). Briefly, Colo 205 cells were plated in 6-well plates at a density of $1 \times 10^{5}$ cells per well and cultured for $24 \mathrm{~h}$. Then cells were treated with or without various concentrations $(1-10 \mu \mathrm{g} / \mathrm{ml})$ of Tan-I for $24 \mathrm{~h}$. After treatment, the cells were fixed with $4 \%$ paraformaldehyde for $30 \mathrm{~min}$ at room temperature, washed with PBS, and permeabilized with $0.1 \%$ Triton X-100 for $2 \mathrm{~min}$ on ice. Then cells were then washed twice and resuspended in $50 \mu 1$ TUNEL reaction mixture ( $5 \mu 1$ TUNEL enzyme containing terminal deoxynucleotidyltransferase, mixed with $45 \mu 1$ TUNEL label containing phycoerythrin-dUTP and dNTP nucleotides) for $60 \mathrm{~min}$ at $37^{\circ} \mathrm{C}$. Negative controls contained only $50 \mu 1$ TUNEL label. Finally, the cells were washed 3 times with buffer (PBS, $0.1 \% \mathrm{NaN}_{3}$, and $10 \%$ autologous serum) and examined by fluorescence microscopy (Nikon, 200X).

DAPI stain. Apoptotic cells were identified by 4,6diamidino-2-phenylindole dihydrochloride (DAPI) staining. Briefly, the Colo 205 cells were plated in 6 well plates at a density of $1 \times 10^{5}$ cells/well and grown for $24 \mathrm{~h}$, then they were treated with or without various concentrations of Tan-I at $0,1,2.5,5$ and $10 \mu \mathrm{g} / \mathrm{ml}$ for $24 \mathrm{~h}$ and were then isolated for DAPI staining. The cells were fixed in $4 \%$ paraformaldehyde for $15 \mathrm{~min}$ at $15-37^{\circ} \mathrm{C}$ then rinsed with PBS, and $0.1 \%$ Triton X-100/in PBS was added for $15 \mathrm{~min}$, followed by further rinsing with PBS. DAPI solution $(1 \mu \mathrm{g} / \mathrm{ml})$ was added into cells, which were then incubated for $30 \mathrm{~min}$ at $37^{\circ} \mathrm{C}$. The cells were then washed with PBS and examined by fluorescence microscopy (Nikon, 200X).
Molecular structure of Tanshinone I

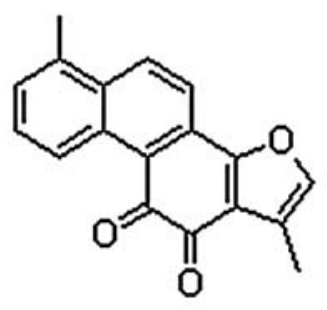

\section{Source: www.chemblink.com/products/568-73-0.htm}

Figure 1. Molecular structure of tanshinone I.

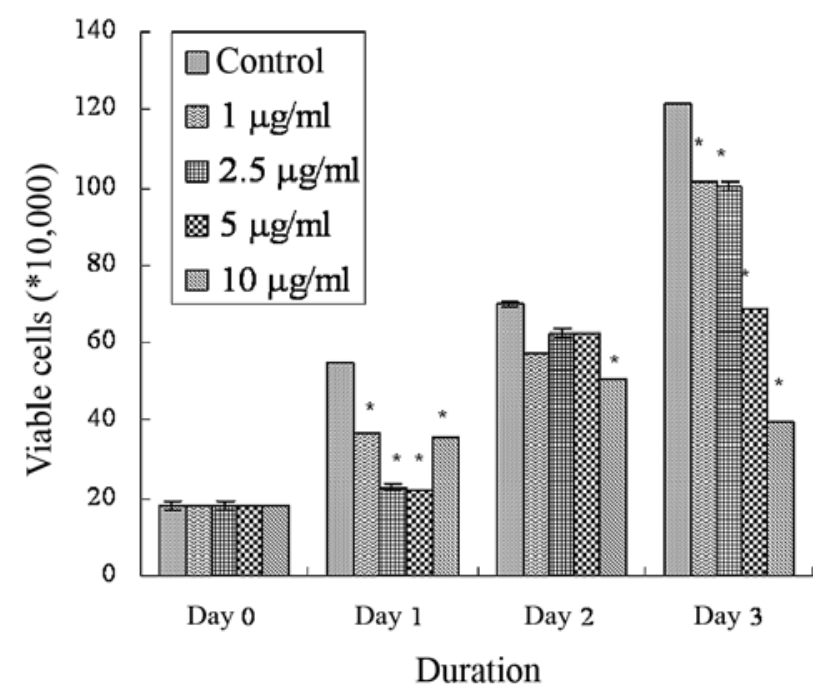

Figure 2. The viable cell numbers of Colo 205 cells were treated with various concentrations (control, 1, 2.5, 5 and $10 \mu \mathrm{g} / \mathrm{ml}$ ) of Tan-I for 24, 48 and $72 \mathrm{~h}$, then cells were collected by centrifugation and the viable cells were determined by trypan blue exclusion as described in Materials and methods. The viable cell numbers significantly decreased with the increase of the Tan-I concentration. Each point is mean \pm S.D. of 3 experiments, ${ }^{*} \mathrm{P}<0.05$.

Protein preparation. For protein extraction, Colo 205 cells ( $2 \times 10^{6}$ cells) were initially seeded on $10-\mathrm{cm}$ cultured dishes and treated with Tan-I at the concentrations of $0,2.5,5$, and $10 \mu \mathrm{g} / \mathrm{ml}$ for 12,24 and $48 \mathrm{~h}$ before the cells were harvested by centrifugation. Proteins were extracted as previously described (16). Briefly, cell pellets were resuspended in modified RIPA buffer (50 mM Tris- $\mathrm{HCl}, \mathrm{pH} 7.5,150 \mathrm{mM}$ $\mathrm{NaCl}, 1 \%$ Nonidet P-40, $0.25 \%$ sodium deoxycholate, $1 \mathrm{mM}$ EGTA, $1 \mathrm{mM}$ DTT, $1 \mathrm{mM}$ PMSF, $1 \mathrm{mM}$ sodium orthovanadate, $1 \mathrm{mM}$ sodium fluoride, $5 \mu \mathrm{g} / \mathrm{ml}$ aprotinin, $5 \mu \mathrm{g} / \mathrm{ml}$ leupeptin and $5 \mu \mathrm{g} / \mathrm{ml}$ antipain) for $30 \mathrm{~min}$ at $4^{\circ} \mathrm{C}$. Lysates were immediately centrifuged at $13,000 \mathrm{x}$ g for $20 \mathrm{~min}$ at $4^{\circ} \mathrm{C}$ and the supernatants were collected, aliquoted (50 $\mu \mathrm{g} /$ tube) and stored at $-80^{\circ} \mathrm{C}$ until assay. Protein concentrations were measured using the Bradford method (15).

Western blotting. All protein samples were separated by $12 \%$ sodium dodecylsulfate polyacrylamide gel electrophoresis 


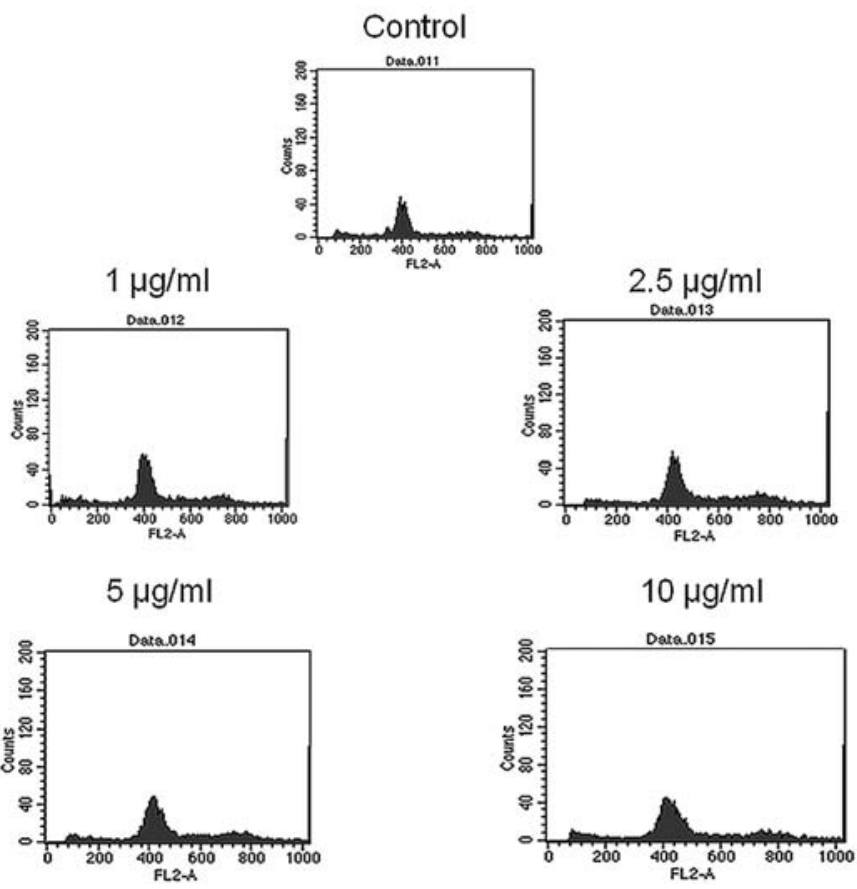

Figure 3. The Colo 205 cells were exposed to various concentrations $(0,1$, $2.5,5$ and $10 \mu \mathrm{g} / \mathrm{ml}$ ) of Tan-I for $48 \mathrm{~h}$, then the cells were harvested and the cell cycle was analyzed by flow cytometry as described in Materials and methods. The G0/G1 phase arrest and sub-G1 phase increased according to the increased concentration of Tan-I.

(SDS-PAGE) (Bio-Rad Life Science Products, Hercules, CA, USA) as previously described (16). The SDS-separated proteins were equilibrated in transfer buffer $(50 \mathrm{mM}$ Tris, pH 9.0, $40 \mathrm{mM}$ glycine, $0.375 \%$ SDS, and $20 \%$ methanol) and transferred onto an Immobilon-P membrane (Millipore Corporation, Bedford, MA, USA). The membranes were incubated with $5 \%$ nonfat dry milk in Tris-buffered saline containing $0.05 \%$ Tween-20 for $1 \mathrm{~h}$. The membranes were then washed and incubated with appropriate dilutions of specific antibodies for p53, p21, bax, caspase-3 and B-actin (Upstate, Lake Placid, NY, USA) at $4^{\circ} \mathrm{C}$ overnight. After incubation with anti-mouse peroxidase-conjugated antibody (Santa Cruz, CA, USA), the immunoreactive bands were visualized using enhanced chemiluminescence (ECL, Amerham Pharmacia Biotech) detection kit. $\beta$-actin was used as an internal control in Western blotting. Immunoreactive bands were scanned and analyzed using a digital scanning densitometer (Molecular Dynamics, Sunnyvale, CA, USA).

Statistical analysis. Values are presented as mean \pm S.D. of control. The Student's t-test was used to analyze the statistical significance between the tanshinone I-treated and control groups. $\mathrm{p}<0.05$ was considered significant.

\section{Results}

The cytotoxicity of Tan-I on human colon cancer Colo 205 cells. Colo 205 cells were treated with various concentrations of Tan-I $(0,1,2.5,5$ and $10 \mu \mathrm{g} / \mathrm{ml})$ for different durations $(24,48$ and $72 \mathrm{~h})$. The results were viewed under contrastphase microscope $(\mathrm{x} 100)$. The results showed viable cells
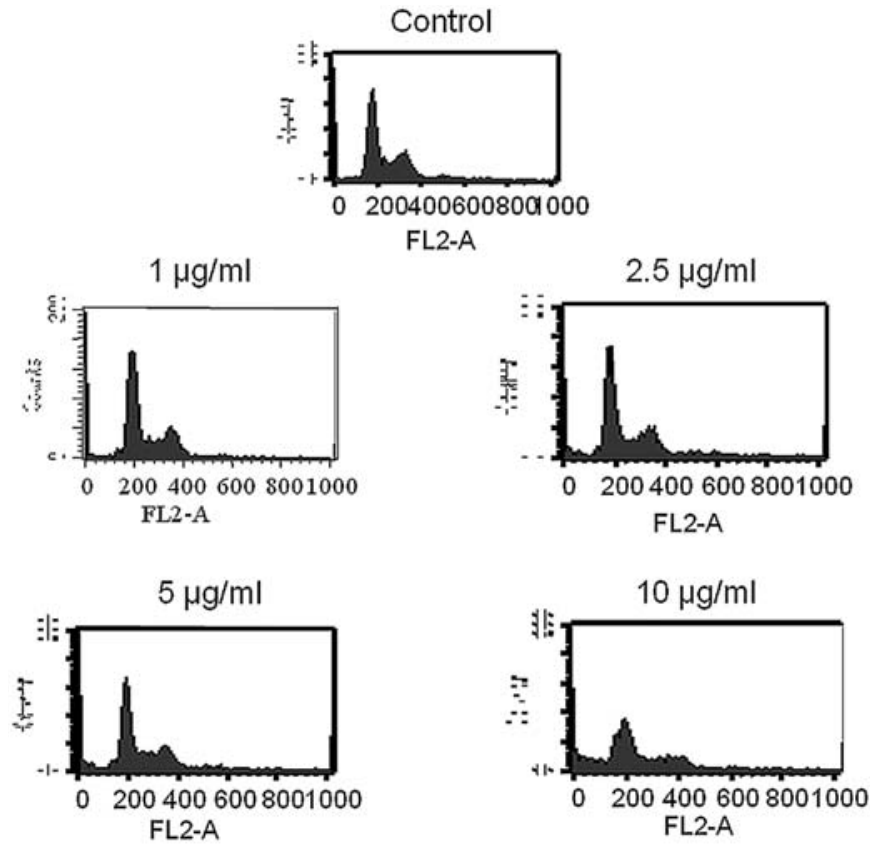

Figure 4. The Colo 205 cells were exposed to various concentrations $(0,1$, $2.5,5$ and $10 \mu \mathrm{g} / \mathrm{ml}$ ) of Tan-I for $72 \mathrm{~h}$, then the cells were harvested and the cell cycle was analyzed by flow cytometry as described in Materials and methods. The G0/G1 phase arrest and sub-G1 phase increased according to the increased concentration of Tan-I.

decreased when the concentration of Tan-I increased, then Colo 205 cells were collected by centrifugation and the viable cells were determined by trypan blue exclusion methods. When the cultured cells were exposed to various concentrations of Tan-I $(0,1,2.5,5$ and $10 \mu \mathrm{g} / \mathrm{ml})$ for $24 \mathrm{~h}$, the numbers of viable cells were $54.83 \pm 1.04,36.67 .0 \pm 0.29,22.92 \pm 0.63$, $22.17 \pm 0.29$ and $35.67 \pm 1.15\left(\times 10^{4}\right)$, respectively. After the cells were exposed to Tan-I at $0,1,2.5,5$ and $10 \mu \mathrm{g} / \mathrm{ml}$ for $48 \mathrm{~h}$, the numbers of viable cells were $70.0 \pm 1,57.33 .7 \pm 5.51$, $62.33 \pm 1.52,62.67 \pm 0.58$ and $51.0 \pm 1.0\left(\times 10^{4}\right)$, respectively. After the cells were exposed to Tan-I at $0,1,2.5,5$ and $10 \mu \mathrm{g} /$ $\mathrm{ml}$ for $72 \mathrm{~h}$, the numbers of viable cells were $121.33 \pm 0.58$, $101.67 \pm 0.58,100.33 \pm 0.58,69 \pm 2$ and $39.67 \pm 0.58\left(\times 10^{4}\right)$, respectively. The results indicated that the viable cell numbers significantly decreased as the Tan I concentration increased. Tanshinone I obviously inhibited Colo 205 cell growth $(\mathrm{p}<0.05)$, demonstrating a dose-dependent effect (Fig. 2).

Tan-I induced Colo 205 cell cycle arrest in G0/G1. To analyze the effect of Tan-I on Colo 205 cell growth and apoptosis, the cell cycle distribution was determined by flow cytometry. The fraction of cells in sub-G1 phase increased after the cells were exposed to various concentrations of Tan-I $(0,1,2.5$, 5 and $10 \mu \mathrm{g} / \mathrm{ml}$ ) for 48 and $72 \mathrm{~h}$. When Colo 205 cells were treated with Tan-I at $0,1,2.5,5$ and $10 \mu \mathrm{g} / \mathrm{ml}$ for $48 \mathrm{~h}$, the percentage of cells in sub-G1 phase increased from $6.44 \%$ to $11.4 \%, 8.58 \%, 8.86 \%$ and $13.1 \%$, respectively (Fig. 3). Treatment with Tan-I at $0,1,2.5,5$ and $10 \mu \mathrm{g} / \mathrm{ml}$ for $72 \mathrm{~h}$, increased the proportion of cells in sub-G1 phase from $3.83 \%$ to $7.22 \%, 8.68 \%, 14.4 \%$ and $32.98 \%$, respectively (Fig. 4). Summary results indicate that Tan-I arrests Colo 205 cells in the $\mathrm{G} 0 / \mathrm{G} 1$ phase with cell accumulation in the sub-G1 phase. 


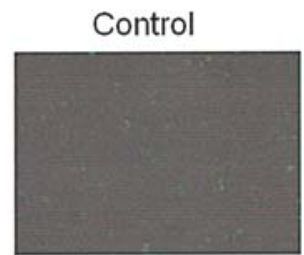

$1 \mu \mathrm{g} / \mathrm{ml}$
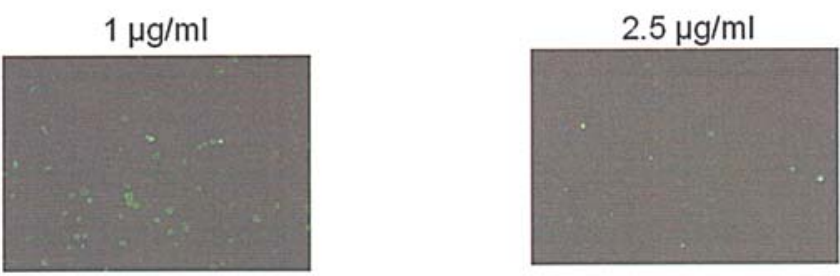

$5 \mu \mathrm{g} / \mathrm{ml}$

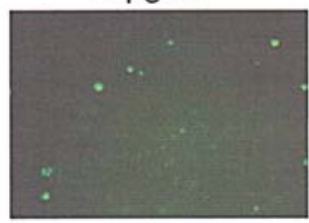

$10 \mu \mathrm{g} / \mathrm{ml}$

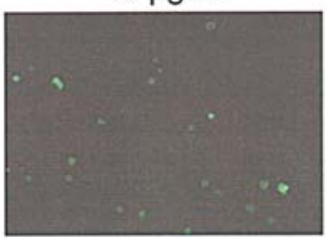

Figure 5. TUNEL assay for the effects of Tan-I on Colo 205 cells apoptosis. The Colo 205 cells were incubated with various concentrations of Tan-I for $24 \mathrm{~h}$ and apoptosis was determined by TUNEL assay as described in Materials and methods.

\section{Control}

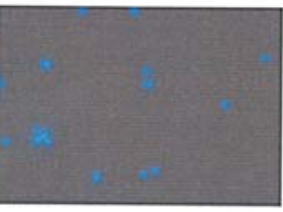

$1 \mu \mathrm{g} / \mathrm{ml}$

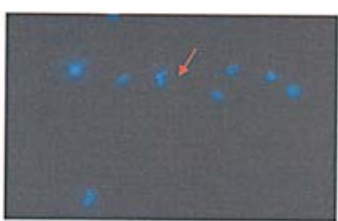

$5 \mu \mathrm{g} / \mathrm{ml}$

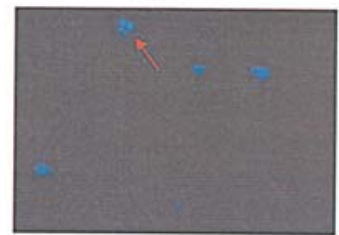

Figure 6. DAPI staining analysis for the effects of Tan-I on Colo 205 cells apoptosis. The Colo 205 cells were incubated with various concentrations of Tan-I for $24 \mathrm{~h}$ and apoptosis was determined by DAPI staining as described in Materials and methods.

To determine the contribution of apoptosis to Tan-Iinduced cytotoxicity, qualitative analyses were performed using TUNEL staining. The number of TUNEL-positive cells significantly increased after Tan-I treatment $(1-10 \mu \mathrm{g} / \mathrm{ml}$ for $24 \mathrm{~h}$ ). The percentage of TUNEL-positive cells by Tan-I treatment at $0,1,2.5,5$ and $10 \mu \mathrm{g} / \mathrm{ml}$ was $2.63,3.99,18.33$,
A
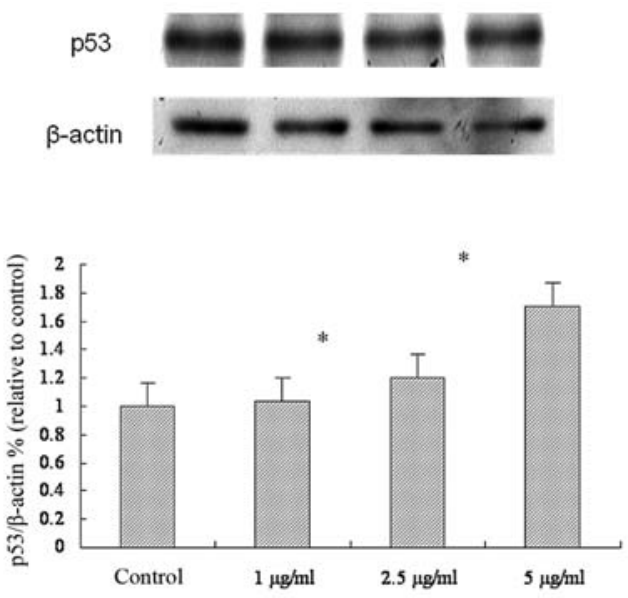

Various concentrations of Tan-I

B
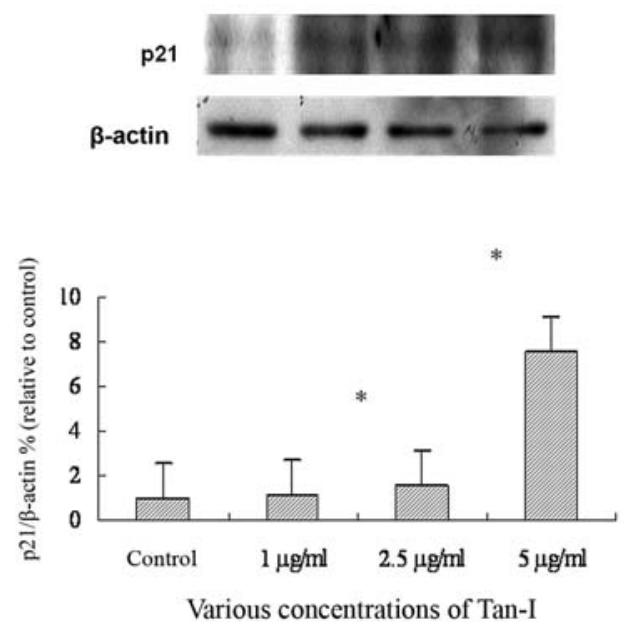

C
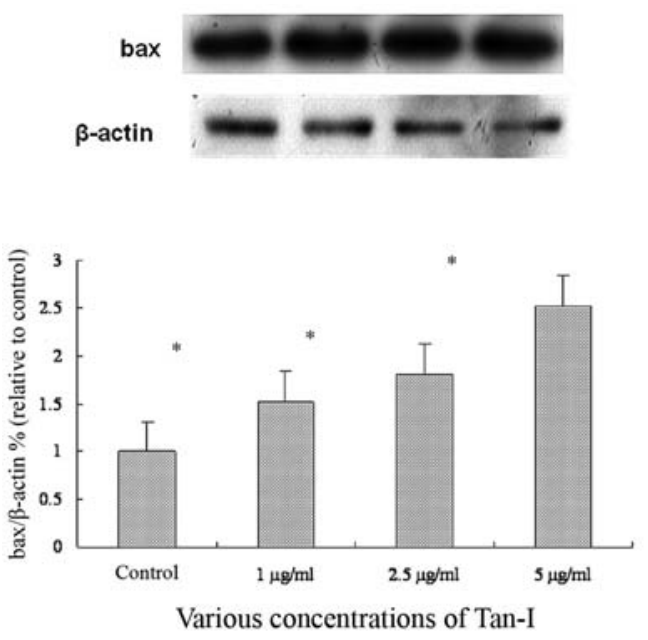

Figure 7. A, B, and C.

22.36 , and $16.33 \%$, respectively. Some cells clearly contained apoptotic bodies, providing further evidence of cell apoptosis (Fig. 5).

To determine the contribution of apoptosis to Tan-Iinduced cytotoxicity, qualitative analyses were performed using DAPI staining. Apoptosis was detected (Fig. 6).

The influence of Tan-I on the expression of cell cycle regulator proteins was investigated by Western blot analysis. 
D

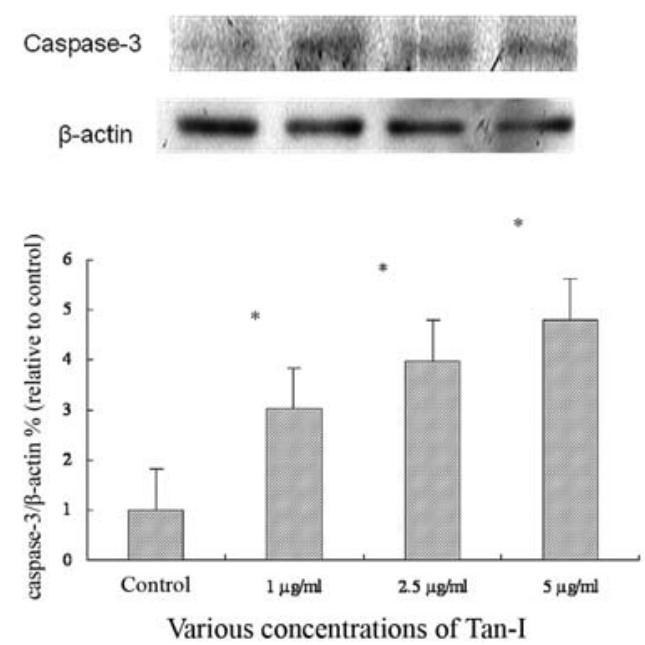

Figure 7. Representative Western blot showing changes on the levels of p53 (A), p21 (B), bax (C) and Caspase-3 (D) in Colo 205 cells after exposure to tanshinone I. The Colo 205 cells $\left(5 \times 10^{6} / \mathrm{ml}\right)$ were treated with various concentrations $(0,1,2.5$ and $5 \mu \mathrm{g} / \mathrm{ml})$ of Tan-I for $24 \mathrm{~h}$, then cytosolic fraction and total protein were prepared and determined as described in Materials and methods. Evaluation of the levels of p53, p21, bax and caspase-3 expression was carried out by Western blotting as described in Materials and methods.

The expressions of the pro-apoptotic protein p53 and cyclindependent kinase inhibitor $\mathrm{p} 21$ protein increased significantly after treatment of Tan-I at the concentration of 2.5 and $5 \mu \mathrm{g} /$ $\mathrm{ml}$ for $24 \mathrm{~h}$ (Fig. 7A and B). To establish the involvement of a mitochondrial apoptotic event, the protein of bax was measured. When cells were treated with Tan-I at the concentration of 2.5 and $5 \mu \mathrm{g} / \mathrm{ml}$ for $24 \mathrm{~h}$, the expressions of bax and caspase-3 protein increased significantly (Fig. 7C and D). We also characterized the involvement of p53 and p21 in Tan-I effects on cultured colon cancer cells. The protein levels of p53 and p21 were significantly increased after

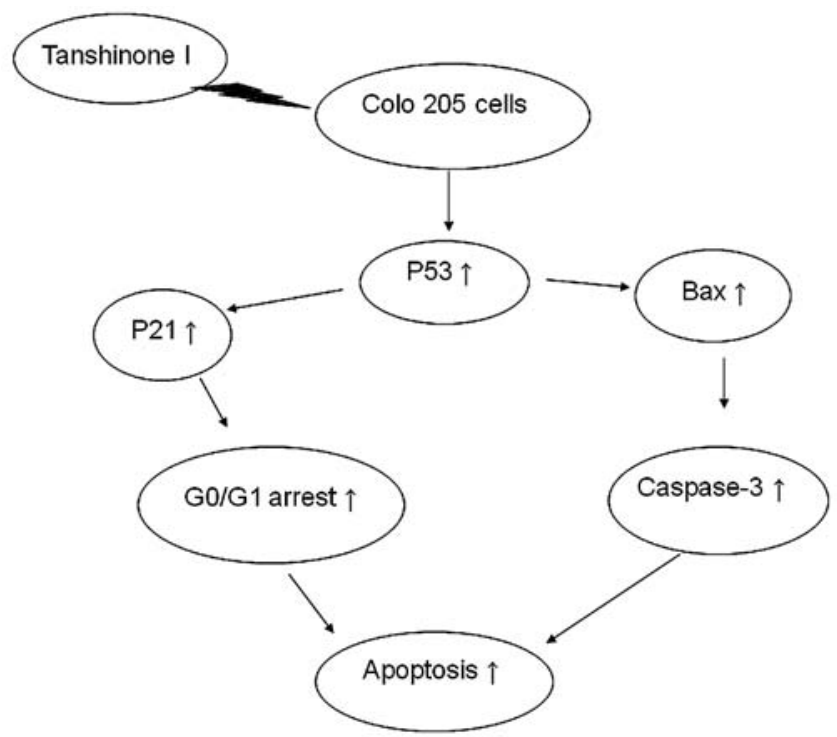

Figure 9. The proposed anti-proliferation signal pathways for Tan-I in human colon cancer Colo 205 cells.

administration of Tan-I (5 and $10 \mu \mathrm{g} / \mathrm{ml}$ ) for $24 \mathrm{~h}$ (Fig. 8A and B).

\section{Discussion}

In this study, the results showed that Tan-I reduced cell growth in a concentration-dependent manner, inducing apoptosis accompanied by an increase in TUNEL staining and in cells in the sub-G1 fraction. This is in agreement with other studies that tanshinone-induced cytotoxicity in Colo 205 and HepG2 carcinoma cell lines (8). It is well documented that p53 is activated and turns on the transcription of one of its downstream genes, $p 21$ (WAF1, Cip-1) (17), and have
A

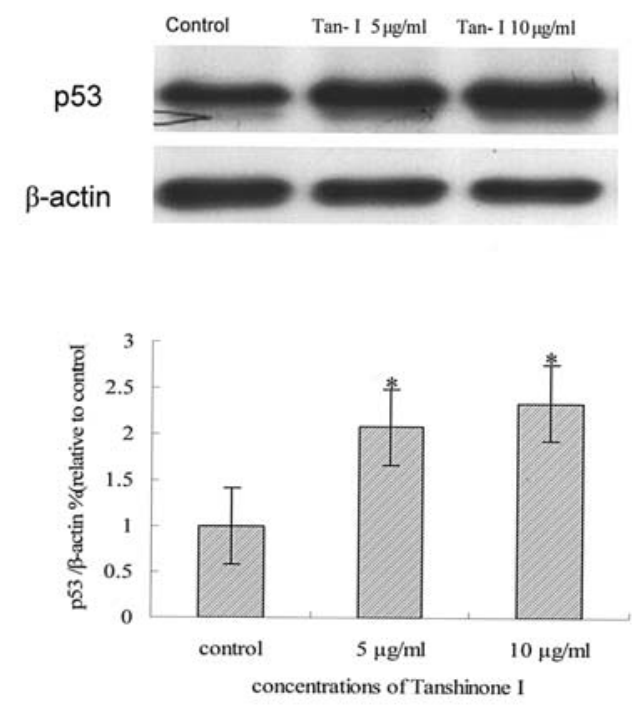

B
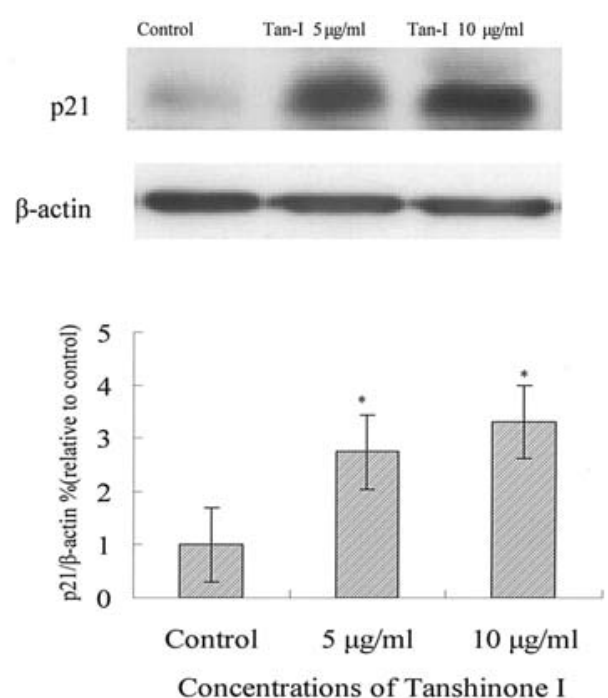

Figure 8. Representative Western blot showing changes on the levels of p53 (A) and p21 (B) in Colo 205 cells after exposure to Tan-I. The Colo 205 cells $\left(5 \times 10^{6} / \mathrm{ml}\right)$ were treated with various concentrations $(0,5$ and $10 \mu \mathrm{g} / \mathrm{ml})$ of Tan-I for $24 \mathrm{~h}$, then cytosolic fraction and total protein were prepared and determined as described in Materials and methods. Evaluation of the levels of p53 and p21 expression was carried out by Western blotting as described in Materials and methods. 
the potential to induce G1 arrest (18) and apoptosis $(19,20)$. The expressions of p53, p21, bax and caspase-3 increased in Tan-I-treated cells. In addition, the cell cycle analysis showed G0/G1 arrest. These findings suggest that Tan-I induces apoptosis in Colo 205 cells through both mitochondrial-mediated intrinsic cell-death pathways and p21-mediated G0/G1cell cycle arrest (Fig. 9). This is agreement with other reports that Tan-I was able to induce apoptosis of human hepatoma hepG2 cells through upregulation of the expression of apoptosis-associated gene Bax (21). These observations showed that the therapeutic potential of Tan-I for colon cancer deserves further study.

\section{Acknowledgements}

This study was supported by grant TCRD95-39 from the Research Section of Buddhist Tzu Chi General Hospital, Hualien, Taiwan. This work was partially supported by Chen-Han Foundation for Education.

\section{References}

1. Martikainen P, Kyprianou N, Tucker RW and Isaacs JT: Programmed death of non-proliferating and androgen-independent prostatic cancer cells. Cancer Res 51: 4693-4701, 1991.

2. Kyprianou N, Bains A and Jacobs S: Induction of apoptosis in androgen-independent human prostatic cancer cells undergoing thymineless death. Prostate 25: 66-75, 1994.

3. Lotan R: Retinoids and apoptosis: implications for cancer chemoprevention and therapy. J Natl Cancer Inst 87: 1655-1657, 1995.

4. Kaufman SH: Induction of endonucleolytic DNA cleavage in human acute myelogenous leukemia cells by etoposide, camptothecin, and other cytotoxic anticancer drugs: a cautionary note. Cancer Res 49: 5870-5878, 1989.

5. Bhalla K, Ibrado AM, Tourkina E, Tang C, Mahoney ME and Huang Y: Taxol induces internucleosomal DNA fragmentation associated with programmed cell death in human myeloid leukemia cells. Leukemia 7: 563-568, 1993.

6. Li ZT, Yang BJ and Ma GE: Chemical studies of Salvia miltiorrhiza f. alba. Yaoxue Xuebao 26: 209-213, 1991.

7. Lin TJ: Antioxidation mechanism of schizandrin and tanshinonatic acid $A$ and their effects on the protection of cardio toxic action of adriamycin. Shengli Kexue Jinzhan 22: 342-345, 1991.
8. Wu WL, Chang WL and Chen CF: Cytotoxic activities of tanshinone against human carcinoma cell lines. Am J Chin Med 19: 207-216, 1991.

9. Liang Y, Yang YM and Yuan SL: Studies on Pharmic mechanism and clinic application of Tanshinone. Tradit Herb Drugs 31: 304-306, 2000.

10. Sung HJ, Choi SM, Yoon Y and An KS: Tanshinone IIA, an ingredient of Salvia miltiorrhiza BUNGE, induces apoptosis in human leukemia cell lines through the activation of caspase-3. Exp Mol Med 31: 174-178, 1999.

11. Yuan SL, Wei YQ, Wang XJ, Xiao F, Li SF and Zhang J: Growth inhibition and apoptosis induction of tanshinone II-A on human hepatocellular carcinoma cells. World J Gastroenterol 10: 2024-2028, 2004.

12. Yuan S, Wang Y, Chen X, Song Y and Yang Y: A study on apoptosis of nasopharyngeal carcinoma cell line induced by Tanshinone II A and its molecular mechanism. Huaxi Yike Daxue Xuebao 33: 84-86,2002.

13. Wang X, Wei Y, Yuan S, Liu G, Lu Y, Zhang J and Wang W: Potential anticancer activity of tanshinone IIA against human breast cancer. Int J Cancer 116: 799-807, 2005.

14. Li TM, Chen GW, Su CC, Lin JG, Yeh CC, Cheng KC and Chung JG: Ellagic acid induced p53/p21 expression, G1 arrest and apoptosis in human bladder cancer T24 cells. Anticancer Res 25: 971-979, 2005.

15. Bradford MM: A rapid and sensitive method for the quantization of microgram quantities of protein using the principle of protein-dye binding. Anal Biochem 72: 248-254, 1976.

16. Chen HC, Hsieh WT, Chang WC and Chung JG: Aloe-emodin induced in vitro $\mathrm{G} 2 / \mathrm{M}$ arrest of cell cycle in human promyelocytic leukemia HL-60 cells. Food Chem Toxicol 42: 1251-1257, 2004.

17. El-Deiry WS, TokinoT, Velculescu VE, Levy DB, Parsons R, Trent JM, Lin D, Mercer WE, Kinzler KW and Vogelstein B: WAF1, a potential mediator of p53 tumor suppression. Cell 75: 817-825, 1993.

18. Deng C, Zhang P, Harper JW, Elledge SJ and Leder P: Mice lacking $\mathrm{p} 21^{\mathrm{CIP} 1 / \mathrm{WAF} 1}$ undergo normal development, but are defective in G1 checkpoint control. Cell 82: 675-684, 1995.

19. Lowe SW, Schmitt EM, Smith SW, Osborne BA and Jacks T: p53 is required for radiation induced apoptosis in mouse thymocytes. Nature 362: 847-849, 1993.

20. Yonish-Rouach E, Resnitzky D, Lotem J, Sachs L, Kimchi A and Oren M: Wild-type p53 induces apoptosis of myeloid leukaemic cells that is inhibited by interleukin-6. Nature 352: 345-347, 1991.

21. Zheng G-C and Li Z-Y: Study on the anti-tumor effect and mechanism of tanshinone I. J Pract Oncol 20: 33-35, 2005. 